\title{
The genus Acacia as invader: the characteristic case of Acacia dealbata Link in Europe
}

\author{
Paula LoREnZO, Luís GonZÁLEZ*, Manuel J. REIGOSA \\ Departamento de Bioloxía Vexetal e Ciencia do Solo, Facultade Bioloxía, Universidade de Vigo, As Lagoas Marcosende 36310 Vigo, Spain
}

(Received 20 May 2009; accepted 7 July 2009)

Keywords:

Acacia dealbata /

biodiversity /

biological attributes /

genus Acacia /

invasive species

Mots-clés :

Acacia dealbata /

biodiversité /

attributs biologiques /

genre Acacia /

espèces envahissantes

\begin{abstract}
- We review current knowledge about the biology of the genus Acacia, and Acacia dealbata Link (silver wattle) in particular, as an invader in Europe, focusing on (i) the biology of the genus Acacia; (ii) biological attributes that are important for the invasiveness of the genus and A. dealbata; (iii) possible hypotheses for the invasion success; and (iv) control methods.

- Several Australian wattles have been recorded as naturalized in Europe. Acacia has attained pest proportions in certain habitats and protected sites (notably coastal dunes, river courses, natural parks and biosphere reserves).

- The spread of Acacia dealbata seems to be assisted by human interference such as soil disturbance and severe fires. The biological attributes favoring invasion by A. dealbata include tolerance of changing soil conditions, the ability to take advantage of environmental disturbance, phenotypic plasticity, vegetative reproduction, fire tolerance and allelopathic potential.

- Different hypotheses explaining invasiveness and transition between invasion steps related to biological attributes as the key factor for A. dealbata invasion are discussed. Effects on the biodiversity of native flora are little understood and studies of suppression of autochthonous species are needed. It is desirable that further studies comparing Acacia at field sites in their native and exotic range should be done.

- Understanding the biology of invasive wattles in Europe is the first step to an effective control method. Studies comparing plant invaders at field sites in their native and invaded areas seem to be most appropriate in order to be able to attack the most vulnerable stages.
\end{abstract}

Résumé - Le genre Acacia comme envahisseur : caractéristiques du cas Acacia dealbata Link en Europe.

- Nous passons en revue les connaissances actuelles sur la biologie du genre Acacia et de Acacia dealbata Link, en particulier comme un envahisseur en Europe, en mettant l'accent sur : (i) la biologie du genre Acacia; (ii) les attributs biologiques qui sont importants pour le caractère envahissant du genre et d'A. dealbata; (iii) les hypothèses possibles pour la réussite de l'invasion et (iv) les méthodes de contrôle.

- Plusieurs acacias australiens ont été enregistrés comme naturalisés en Europe. Acacia a atteint la proportion de nuisible dans certains habitats et sites protégés (notamment des dunes côtières, des cours d'eau, des parcs naturels et des réserves de la biosphère).

- La propagation de l'Acacia dealbata semble avoir été aidée par l'intervention humaine, telle que la perturbation des sols et de graves incendies. Les attributs biologiques favorisant l'invasion par A. dealbata incluent la tolérance aux changements des conditions du sol, la capacité à tirer profit des perturbations de l'environnement, la plasticité phénotypique, la reproduction végétative, la tolérance au feu, et le potentiel allélopathique.

- Différentes hypothèses expliquant le caractère invasif et la transition entre les phases de l'invasion en relation avec les attributs biologiques comme facteur clé pour l'invasion d'A. dealbata sont discutées. Les effets sur la biodiversité de la flore sont mal compris et des études sur la suppression des espèces autochtones sont nécessaires. Il est souhaitable que d'autres études comparant Acacia sur le terrain dans leurs sites et dans des régions exotiques soient faites.

- Comprendre la biologie des espèces d'Acacia invasives en Europe est la première étape d'une méthode de contrôle efficace. Les études comparant les envahisseurs végétaux sur le terrain dans leurs sites et dans les zones envahies semblent être plus appropriées afin d'être en mesure d'attaquer les étapes les plus vulnérables.

\footnotetext{
*Corresponding author: luis@uvigo.es
} 
Table I. List of Acacia species with invasive potential in Europe.

\begin{tabular}{llll}
\hline France & \multicolumn{1}{c}{ Italy } & \multicolumn{1}{c}{ Portugal } & \multicolumn{1}{c}{ Spain } \\
\hline A. dealbata Link & A. dealbata Link & A. dealbata Link. & Aealbata Link \\
A. melanoxylon R.Br. & A. melanoxylon R.Br. & A. melanoxylon R.Br. & A. melanoxylon R.Br. \\
A. longifolia (Andrews) Willd. & A. longifolia (Andrews) Willd. & A. longifolia (Andrews) Willd. A. longifolia (Andrews) Willd. \\
A. retinodes Schlecht. & A. retinodes Schlecht. & A. retinodes Schlecht. & A. retinodes Schlecht. \\
A. saligna (Labill) Wendl. fil. & A. saligna (Labill) Wendl. fil. & A. saligna (Labill) Wendl. fil. & A. saligna (Labill) Wendl. fil. \\
& A. mearnsii De Wild. & A. mearnsii De Wild. & \\
& A. pycnantha Bentham & A. pycnantha Bentham & \\
& & A. karroo Hayne & \\
\hline
\end{tabular}

\section{INTRODUCTION}

Ecosystem structure and functioning are often seriously affected by invasive Acacia species, leading to ecological homogenization of the landscape. Management of Acacia is difficult due to their tendency to invade native forest and cultivated areas, resulting in serious problems (Blakesley et al., 2002).

The genus Acacia (wattles) belongs to the family Mimosaceae. There are almost 1380 species of Acacia found throughout the world and close to 1000 of these are to be found in Australia, as well as 144 species in the African region (Madagascar included), 89 species in Asia, and about 185 species in North and South America.

The current classification (Maslin et al., 2003; Orchard and Maslin, 2003) recognizes five major groups within Acacia: Acacia, Aculeiferum, Phyllodineae (to which Acacia dealbata was assigned), Filicinae and the "Acacia coulteri" group.

In Europe, the climate has perhaps tended to restrict the spread of the genus Acacia, which has generally not reached pest proportions except in particular sites and sensitive habitats (coastal dunes, river courses, natural parks and biosphere reserves). Nevertheless, there are at least eight Australian wattles which are recorded as being naturalized and have become potential pest plants in the south of Europe (Tab. I). Indeed, wattle invasions of Europe (Marchante et al., 2004; Sheppard et al., 2006), South Africa (French and Major, 2001) and the Florida Everglades (Austin, 1978) have caused great concern among naturalists, botanists and conservationists in these regions, where some of the worst examples of eradication of native flora by Acacia species have been seen (Cronk and Fuller, 1995). Wattles threaten native habitats by competing with indigenous vegetation, replacing grass communities, reducing native biodiversity and increasing water loss from riparian zones (Hoffmann et al., 2002). In addition to its great colonizing capacity, it typically dominates the colonized site, with understory species scarce and present only with low cover (Carballeira and Reigosa, 1999).

At present, the species Acacia dealbata, A. melanoxylon and $A$. longifolia are the most prolific invaders in France, Italy, Portugal and Spain, especially in conservation areas. The most widespread species is probably A. dealbata, a tree that is widely naturalized in southern Europe (Sheppard et al., 2006). In its natural geographic range $A$. dealbata is common in a wide range of plant communities (dry and wet forests, grassy and heathy woodlands, grasslands and riparian ecosystems), and this allows it to invade most ecosystems in southern Europe.

This review has two aims. First, we briefly review current knowledge about the biology of Acacia species as invaders. Second, we discuss the biological attributes that are key factors for the invasiveness of the silver wattle A. dealbata. Although there are several wattle species present in southern Europe (Tab. I), only some have been studied in reasonable depth by researchers (e.g. A. longifolia). In this paper we have solely concentrated on $A$. dealbata. We propose relevant hypotheses affecting aspects of $A$. dealbata demography and also suggest possible problems related to lack of information. There is enormous variation within and between species, areas, habitats and years. In the case of $A$. dealbata expansion, context (e.g. local climate, and type, intensity and frequency of disturbance) is all-important (Midgley and Bond, 2001). Acacia species can be usefully classified into groups (Midgley and Bond, 2001), and this might significantly aid in the understanding of $A$. dealbata invasion. Notably, it might provide a basis for extrapolating data and inferences obtained for other closely related species, such as A. mearnsii, A. nanodealbata and A. decurrens (Bauhus et al., 2004).

\section{BIOLOGY OF THE GENUS AND A. DEALBATA}

\subsection{Habitat and geographical range}

Acacia is a cosmopolitan genus distributed in the AustraliaPacific region, throughout the south of Asia, Africa and in North and South America (Fig. 1). The genus Acacia occupies vast areas of these domains and is to be found in a wide range of different habitats, from coastal to subalpine regions, and from high rainfall to arid inland areas, growing in tropical, subtropical and warm temperate regions (Maslin and McDonald, 2004). Nevertheless, most species are distributed primarily in the dry tropics, and several Australian Acacia species have become highly invasive weeds around the world (Blakesley et al., 2002), including southern Europe.

Acacia dealbata is native to Australia, occurring naturally on the tablelands and western slopes of New South Wales, and also widespread in Victoria and eastern Tasmania. It inhabits areas with over $500 \mathrm{~mm}$ rainfall (oceanic climate), usually at altitudes from 350-1000 $\mathrm{m}$ above sea level (May and Attiwill, 2003) (Fig. 1). 


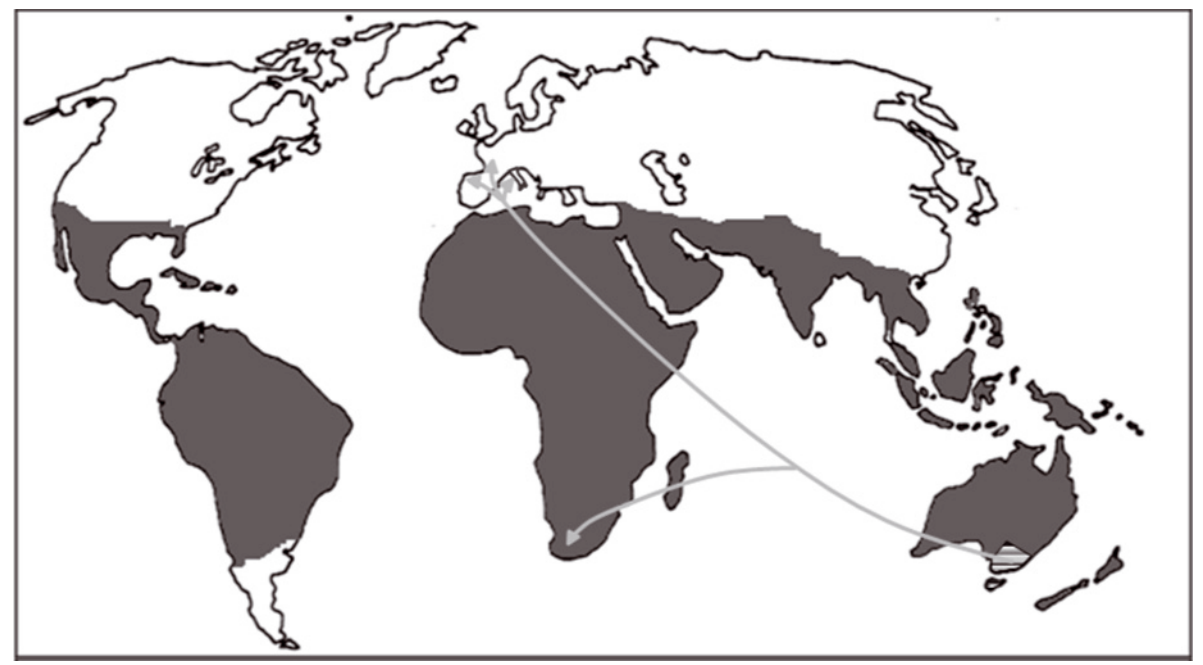

Figure 1. Gray area indicates world natural distribution map for the genus Acacia. Native areas comprise the Australia/Pacific region, South Asia, Africa and the Americas. Lined area indicates native distribution map for Acacia dealbata. As shown, the native range includes Tasmania, Victoria and New South Wales. Arrows show the new distribution area of A. dealbata from the native range.

A. dealbata was first introduced in Europe towards 1800 (Sheppard et al., 2006). It was planted as an ornamental in the 19th century in many areas of southern Europe, which offered favorable climates for its development, with sufficient sun exposure and little frosts. At present, it is widely naturalized in southwest Europe (Sheppard et al., 2006; Tutin et al., 2001) (Fig. 1). It occurs in riparian zones, water courses and sunny edges of pinewoods, or on south and westfacing slopes, where it forms dense stands that choke the natural vegetation. Acacia dealbata often invades areas under intensive agricultural use and further away from the sea than the other Acacia species present in these regions (Aguiar et al., 2001). Acacia dealbata is a problem species in Portugal (Almeida and Freitas, 2006), northwest Spain, where it is threatening the native flora and becoming a serious environmental problem (Carballeira and Reigosa, 1999), and in France and Italy, where it is locally dominant in the Mediterranean littoral (Sheppard et al., 2006) (Fig. 1).

\subsection{Reproductive biology}

Although pollination and seed set are crucial aspects of Acacia biology, they remain unstudied for most species (Stone et al., 2003). Knowledge of this aspect of biology would be very useful for understanding and assessing the impact of invading Acacia species on native flora throughout the world. There has been extensive work on the reproductive biology of Australian wattles, but mainly within their native geographic range. The literature on reproductive biology in other areas is surprisingly sparse (Kenrick, 2003). Despite this, different subgroupings of Acacia share many basic reproductive biological traits.

Acacia species flower throughout the year, although within their native ranges most species flower during spring and summer. Increased rainfall has been associated with higher inflorescence production (Broadhurst and Young, 2006). In Europe, within its naturalized range, A. dealbata flowers from January to March (Reigosa, 1987), but reproductive phenology is rather variable (Fig. 2).

The open structure of the Acacia inflorescence makes it accessible to a wide diversity of visitors. Stone et al. (2003) indicate that Acacia flower visitors can be divided into the following three trophic groups: specialist pollen and flower feeders (bees, beetles, many true flies), specialist nectar feeders (birds, butterflies and bee flies [Bombylidae]), and opportunist foragers (flies, ants and wasps). Despite the large number of visitors it is possible that only a subset of them are effective pollinators (Stone et al., 2003).

There has been no specific research into the reproductive biology of A. dealbata, but in the old subgenus Phyllodineae, pollen release is gradual, and if this is the case in A. dealbata then it implies an enhanced capacity to invade new locations by extending the number of possible visitors, even nocturnal pollinators (Stone et al., 2003). Certainly, the flowers of A. dealbata do not show complex morphology restricting access to a small group of specialized pollinators. As a consequence, in a new area susceptible to invasion, a wide variety of native insects can visit silver wattle flowers and become involved in pollination because of the spatial presentation of pollen on the surface of the flowers (Kenrick, 2003), acting as a floral reward to pollinators (Stone et al., 2003). Nectar is only produced in small quantities and if present is located inside and at the base of the corolla tube, accessible only to specific insects. Floral scent (another insect attractant) is located in the anthers and associated structures (Tybirk, 1993). There is no published information about the pollination efficiency of A. dealbata in Europe, but it is reasonable to suppose that the scents and other chemical rewards produced by floral structures will reflect the net balance of selective forces imposed by pollinators in the native range. It is important to note that a given set of rewards may recruit different pollinators in a new 


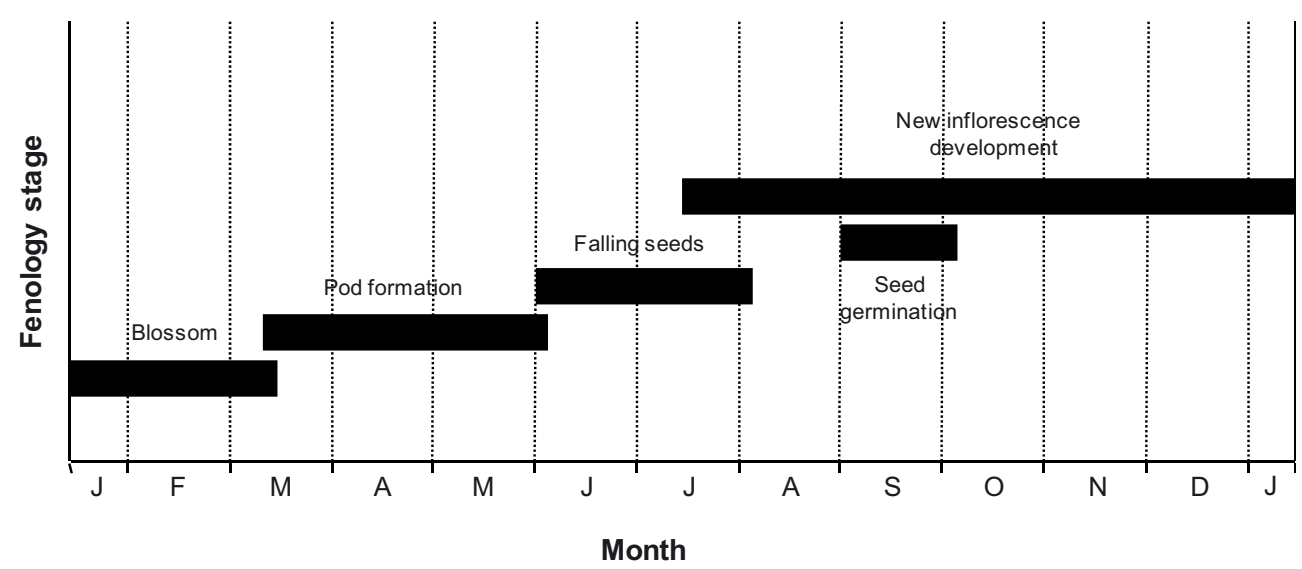

Figure 2. Duration of the reproductive period of Acacia dealbata in Galicia (NW Spain), including the timing of five phases (inflorescence development, flowering, pod formation, seed maturation and germination), based on monitoring of marked individuals and transect data.

Table II. Flowering phenology and longevity of A. dealbata. Flower-head longevity is the total period in days from the opening of the first flower on a flower head to senescence of the flower head: duration of female phase is based on stigma extension and visible state in open flowers; duration of male phase is based on the physical state of the stamens in open flowers.

\begin{tabular}{lcccc}
\hline Location & $\begin{array}{c}\text { Flower-head } \\
\text { longevity (days) }\end{array}$ & $\begin{array}{c}\text { Duration of female } \\
\text { phase (days) }\end{array}$ & $\begin{array}{c}\text { Duration of male } \\
\text { phase (days) }\end{array}$ \\
\hline A. dealbata & Southern Victoria (Australia) $^{\mathrm{a}}$ & $8-15$ & $1-8$ & $1-8$ \\
\hline A. dealbata & Galicia (NW Spain) $^{\mathrm{b}}$ & $10-22$ & $5-13$ & $3-14$ \\
\hline
\end{tabular}

${ }^{a}$ Data from Stone et al. (2003). ${ }^{\text {b }}$ Data from authors (2007). The overlap time between the two phases was $2-4 \mathrm{~d}$.

distribution area, or indeed act against pollination of the native flora after rain and release into the soil solution (Callaway and Ridenour, 2004).

Separation of male and female functions in time to reduce the risk of selfpollination is widespread in wattles (Stone et al., 2003). Most species of the genus Acacia are protogynous, i.e. female flowering precedes male flowering (Kenrick, 2003; Sedgley and Harbard, 1993). Flowering is often asynchronous over a single tree and over a single flower head (Stone et al., 2003), so pollination by visitors is needed. Data on separation of male and female flowering in A. dealbata are summarized in Table II.

\subsection{Dispersal of propagules}

The genus Acacia shows distinctive adaptations for seed dispersal. Wattles have arillate appendages that suggest active dispersal by birds (Davidson and Morton, 1984) and ants (Edwards and Westoby, 1996), and in areas of invasion members of this taxon are adapted for propagule dissemination by ruminant ungulates (Lamprey, 1967; Razanamandranto et al., 2004), as well as by water and wind (Lamprey et al., 1974; Tybirk, 1993). Ingestion by large herbivores facilitates germination by scarification of the seed coat (Or and Ward, 2003). Other less common agents include floodwaters (Kriticos et al., 2003b), meat ants (Whitney, 2002), elephants (Dudley, 1999), foxes (Varela and Bucher, 2006) and domestic livestock (Brown and Carter, 1998).
Davidson and Morton (1984) have separated Acacia species based on aril color, legume morphology and seed orientation in pods, creating two different groups. These authors related legume and seed characteristics to dispersal agents. Acacia dealbata is a tree whose seeds have a white aril and a longitudinal orientation in the pods, thus falling into Davidson and Morton's group I. White arils are often indicative of myrmecochory (Whitney, 2002), and if it is true that interactions between myrmecochorous plants and ants are often not highly specialized or speciesspecific (see Horvitz and Beattie, 1980), this might be decisive in A. dealbata dispersion in new habitats.

Ninety percent of the world's myrmecochores are found in the southern hemisphere (Gómez and Espadaler, 1998), while ornythochory is more common in the northern hemisphere. Plants typically expend more energy per milligram of propagule for bird dispersal than for ant dispersal (Davidson and Morton, 1984). In southern Europe, A. dealbata competes mostly with ornythochores and, thus, the relative costs and benefits of propagule dispersal could be lower for the invasive Acacia. In Australia seeds of A. dealbata have higher rates of parasitic infestation (particularly by bruchid beetles) than those of ornythochorous species, but it is possible that seed parasites are not present in Europe. In this connection, Elton (1958) suggests that invaders often perform better in their introduced range than in their native range because they are no longer exposed to their specialist enemies. On the other hand, invasive $A$. dealbata may benefit from dispersal by ants in open areas with scarce adult trees (and, thus, 
reduced bird densities), or during early population establishment when fruiting biomass may be inadequate to attract birds (see Davidson and Morton, 1984). However, we should note that very little empirical information about these aspects is available for A. dealbata.

\section{BIOLOGICAL ATTRIBUTES AS KEY FACTORS FOR A. DEALBATA INVASION}

Important reasons for the success of many Australian plants as invaders in southern Europe, often in high-quality indigenous vegetation, include a suite of preadaptive biological attributes, such as long-term soil-stored seed banks, ability to thrive in low-nutrient substrates, generalist pollination syndromes and generalist seed-dispersal syndromes (Carr, 2001). Sharma et al. (2005a) have suggested that it would be of value to be able to predict whether an alien plant will become an invader or not, based on a few biological characteristics. Certainly, this is an interesting proposal. On the basis of the available information, the biological attributes conferring invasiveness for A. dealbata can be grouped into four major categories as described below.

\subsection{Taking advantage of disturbance and adaptability to changing conditions}

Disturbance events of different types and intensities are common and widespread in most ecosystems. Lake and Leishman (2004) found that undisturbed sites do not generally support exotic plants. Therefore, it is likely that invasive species use disturbances to colonize new habitats (Hierro et al., 2005). Major disturbance processes include human soil disturbance and fire. In addition, some wattles are dependent on soil disturbance for establishment and need fire to spread and to germinate (Cheal, 2002; Spooner, 2005). Moreover, soil disturbances provoked by human activities appear to favor wattles with strong resprouting ability (Spooner, 2005).

Several invasive Acacia species are recognized as colonizing disturbed sites (Osunkoya et al., 2004; Osunkoya et al., 2005). Acacia mearnsii has been recorded as an invader in completely disturbed forests (Gerald and Obua, 2005). Bearing in mind that $A$. mearnsii is a closely related species to A. dealbata, we can expect this latter to show a similar capacity for invasiveness at disturbed sites.

Like other Acacia species, A. dealbata is a nitrogen-fixing plant (Rama Devi and Prasad, 1991). Specifically, it has been reported that $A$. dealbata increases concentrations of potentially available nitrogen, total nitrogen and organic carbon, and reduces the bulk density of the soil, but it does not affect the amount of total nitrogen in soil (May and Attiwill, 2003). High rates of nitrification in A. dealbata forests are associated with high levels of nitrate reductase activity in tissues (Adams and Attiwill, 1982). Acacia dealbata also shows a capacity for high water consumption (de Neergaard et al., 2005). It therefore presents great plasticity in its response to soil water availability and other environmental conditions (Pohlman et al., 2005) and is capable of modifying soil conditions, and consequently the surrounding vegetation (i.e. the autochthonous flora).

It is well known that fire positively affects the germination of most Acacia species, and some species show strong germination across a broad range of temperatures (Brown et al., 2003). In fact, Acacias around the world seem to need fire to germinate (Danthu et al., 2003; Dennill and Donnelly, 1991; Hunt et al., 1999; Spooner, 2005) and a recent study shows that fire-derived compounds may have a significant effect on the post-fire seedling ecology of wattles (Kulkarni et al., 2007). In fact, most Acacia species are highly adapted to fire, with hardcoated seeds (Spooner, 2005). In Mediterranean-climate ecosystems, wet tropics and semi-arid zones, it seems that heat shock due to fire could break seed dormancy (Danthu et al., 2003). Moreover, it is known that this species has highly competitive early growth following fire in wet native forest (Hickey, 1994). Midgley and Bond (2001) report that most wattles can send out shoots, at least after a single mild fire or mild injury. In Europe, and notably in Spain and Portugal, A. dealbata occupies wet temperate regions that have been severely affected by several wildfires in recent years (Martínez et al., 2009). This has had two consequences: the invaded range is progressively increasing, and A. dealbata is becoming a more dangerous species in these areas.

\subsection{Phenotypic plasticity and geographical range}

Phenotypic plasticity is the ability of a genotype to modify growth and development in response to changes in the environment (Callaway et al., 2003; Sharma et al., 2005b). By changing physiological traits in response to environmental conditions, plants are able to adapt to a range of environments and, thus, utilize a wider range of habitats than would be possible if all traits were "fixed" (Sultan, 1995).

Widespread Acacia species show a higher photosynthetic capacity and WUE (Water-Use Efficiency) at low soil water availability than restricted-range Acacia species (Ball et al., 1995). They also have higher leaf nitrogen contents (Wright et al., 2001) and greater plasticity in SLA (Specific Leaf Area) (Pohlman et al., 2005). Pohlman et al. (2005) have also shown that widespread species, like A. dealbata, display greater plasticity than restricted-range species in key seedling establishment traits. These authors suggested that $A$. dealbata seedlings showed fundamental differences in the physiology and plasticity of leaflets with respect to restricted-range species. These traits would help $A$. dealbata to efficiently utilize diverse habitats in invaded regions. When it was introduced in southern Europe, A. dealbata colonized new habitats with similar climate and environmental characteristics to its native habitats of origin aided by its adaptative traits and genetic plasticity (Carr, 2001). Its invasive potential is probably being enhanced by global climate change, which increases the areas susceptible to colonization (Kriticos et al., 2003b). Furthermore, when A. dealbata arrives in new environments, it can cross with other wattles (Sheppard et al., 2006), creating novel hybrids which may colonize new environments. Thus, both global 
climate change and hybridization could allow A. dealbata to extend its distribution range and colonize new environments.

\subsection{Vegetative reproduction}

Acacia dealbata are well known for their impressive floral displays among vegetation communities across southern $\mathrm{Eu}-$ rope. This could be interpreted as an indicator of population health and persistence in the environment. Although plants produce flowers, legumes and seed, they do not necessarily contribute to expanding the plant (Broadhurst and Young, 2006). Vegetative reproduction becomes crucial here. There have been few studies of "natural" vegetative reproduction of Acacia species. However, it is well known that some species have strong resprouting ability (Broadhurst and Young, 2006; Spooner, 2005) and it is the major dispersal mechanism in Europe. A. dealbata reproduces by seeds but it can spread by rhizomes and readily sprouts after cutting or damage. It is also able to counteract reduced reproductive output by vegetative persistence (Wilcock and Neiland, 2002), A. dealbata can propagate by re-sprouting after cutting, fire or frost (Sheppard et al., 2006), giving the plant a high capacity to resist most types of mechanical control. Its rapid invasion of new environments may be facilitated by its capacity for growth by vegetative reproduction.

\subsection{Allelopathy}

Allelopathy has been defined as the stimulatory or inhibitory effect of one plant (including microorganisms) on other plants through the release of chemical compounds into the environment (Rice, 1984). In recent years, many studies of the invasive characteristic of wattles have demonstrated phytotoxic capacities, as summarized in Table III. However, most experiments researching $A$. dealbata allelopathy have been laboratory experiments (Lorenzo et al., 2008) and rather little is known about allelopathic effects of Acacia in the field.

In Galicia (our region in NW Spain, with widespread A. dealbata invasion), Carballeira and Reigosa (1999) have demonstrated that $A$. dealbata leachates show strong inhibitory effects on germination and growth of Lactuca sativa during the A. dealbata flowering period. A. dealbata flowering coincides in time with the germination period of native understory species. This enhances the allelopathic character of A. dealbata. Additionally, A. dealbata has great allelopathic capacity potential through several mechanisms, such as leachates fluctuating over the year and over shorter periods of time (Carballeira and Reigosa, 1999; Lorenzo et al., 2008).

Most compounds secreted by plants are secondary metabolites produced as offshoots of the plant's primary metabolic pathways (Hadacek, 2002). A number of secreted secondary metabolites have been reported from various Acacia species, most of them beneficial to other plants. However, there are also some harmful substances (Seigler, 2002), among them complex phenolic compounds (Seigler, 2003). In A. dealbata

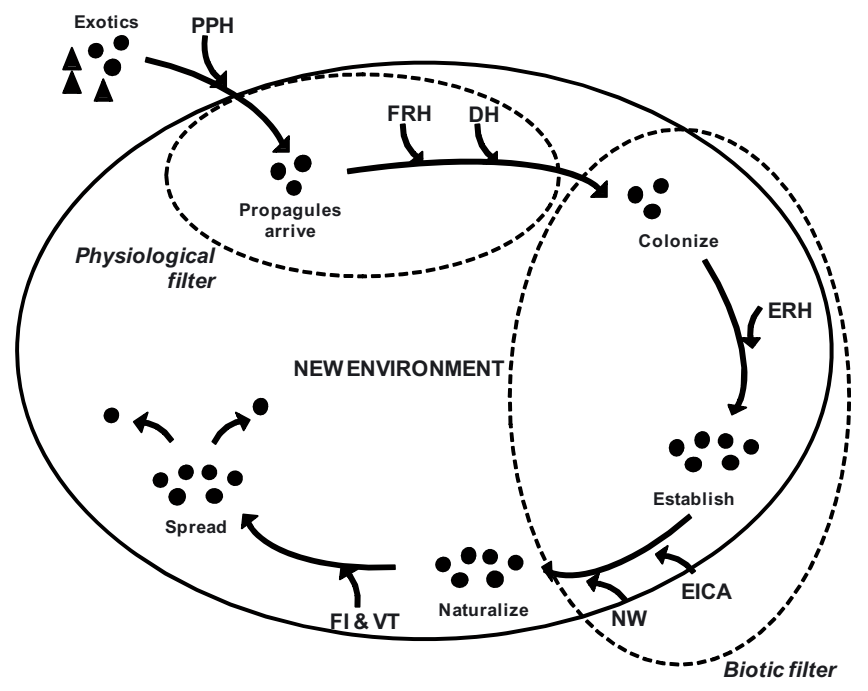

Figure 3. Diagram showing several phases of Acacia dealbata invasion in relation to the different hypotheses for invasiveness and for transition from one phase to another. The discontinuous line is a schematic representation of major barriers to the spread of introduced plants. PPH, propagule pressure hypothesis; FRH, fluctuating resource hypothesis; DH, disturbance hypothesis; ERH, enemy release hypothesis; EICA, evolution of increased competitive ability hypothesis; NW, novel weapons hypothesis; FI, faunal interaction; VT, vegetative traits. Adapted from Sharma et al. (2005a).

there can be found iminoacids (Kunii et al., 1996), chalcone glycosides (Imperato, 1982), triterpenes (Pereira et al., 1996), sterols (Freire et al., 2005) and $p$-Hydroxycinnamic acids (especially caffeic acid esters with long-chain fatty alcohols, Freire et al., 2007), some of which can act as allelochemicals (Reigosa et al., 1999). When A. dealbata was introduced into NW Spain, it brought "novel weapons" (Callaway and Aschehoug, 2000) that interfere with native species (Carballeira and Reigosa, 1999; Lorenzo et al., 2008).

\section{POSSIBLE HYPOTHESES FOR THE INVASION SUCCESS OF ACACIA DEALBATA}

There are hundreds of thousands of plant species, but relatively few have the capacity to invade alien environments. Therefore, what determines whether a given potential invader will be present in a given location? One way of answering this question is in terms of "filters" (see Lambers et al., 1998). Acacia, for example, is absent from some locations for historical reasons (such as plant evolution, or continental drift) despite appropriate environmental conditions. This is a historical filter. Acacia in other locations is absent because it does not have appropriate physiological traits to survive (for example, it cannot tolerate extreme drought). This is a physiological filter. Biotic interactions between exotic and autochthonous species in the new environment may likewise prevent Acacia establishment. This would be a biological filter (Lortie et al., 2004).

Diverse hypotheses have been put forward to explain how invasive plants can overcome these "filters" (Fig. 3, see Hierro 
Table III. Phytotoxic capacity of various Acacia species.

\begin{tabular}{|c|c|c|c|}
\hline Donor species & Phytotoxic effect & Target species & Reference \\
\hline \multirow[t]{2}{*}{$\begin{array}{l}\text { Acacia auriculiformis } \\
\text { A.Cunn. ex Benth. }\end{array}$} & $\begin{array}{l}\text { Inhibitory effect on germination, } \\
\text { root and shoot elongation and } \\
\text { development of lateral roots }\end{array}$ & $\begin{array}{l}\text { Brassica juncea L. } \\
\text { Phaseolus mungo L. } \\
\text { Raphanus sativus L. } \\
\text { Vigna unguiculata (L.) Walp. } \\
\text { Cicer arietinum L. }\end{array}$ & (Rafiqul Hoque et al., 2003) \\
\hline & $\begin{array}{l}\text { Weak effect on root weight/root } \\
\text { length ratio }\end{array}$ & Oriza sativa $\mathrm{L}$. & (Bernhard-Reversat, 1999) \\
\hline Acacia sp. & $\begin{array}{l}\text { Strong inhibitory effect on seed } \\
\text { germination }\end{array}$ & Lepidium sativum $\mathrm{L}$. & (Heil et al., 2002) \\
\hline $\begin{array}{l}\text { Acacia confusa Merr. } \\
\text { Acacia } \mathrm{sp} .\end{array}$ & $\begin{array}{l}\text { Inhibition of radicle growth of } \\
\text { test plants }\end{array}$ & $\begin{array}{l}\text { Lactuca sativa } \mathrm{L} . \\
\text { Brassica chinensis } \mathrm{L} . \\
\text { Medicago sativa } \mathrm{L} .\end{array}$ & (Chou et al., 1998) \\
\hline Acacia mangium Willd & Reduction of height growth & $\begin{array}{l}\text { Shorea leprosula Miq. } \\
\text { Shorea stenoptera } \text { Burck }\end{array}$ & (Anwar, 1992) \\
\hline Acacia mearnsii De Wild. & $\begin{array}{l}\text { Suppression of weed } \\
\text { establishment }\end{array}$ & $\begin{array}{l}\text { Conyza sumatrensis (Retz.) } \\
\text { E.Walker } \\
\text { Trifolium } \text { sp. } \\
\text { Echinochloa utilis Ohwi \& Yab. } \\
\text { Lactuca sativa L. }\end{array}$ & (Schumann et al., 1995) \\
\hline $\begin{array}{l}\text { Acacia nilotica (L.) Willd. } \\
\text { ex. Del. }\end{array}$ & $\begin{array}{l}\text { Stronger allelopathic effect on } \\
\text { growth }\end{array}$ & Grasses under tree & (Bashir Hussain, 1991) \\
\hline
\end{tabular}

et al., 2005, for review), but we do not currently know the relative importance of these hypotheses in the case of Acacia, or in particular, for A. dealbata. Certainly, this species' invasion success is not likely to be explained by a single hypothesis.

In relation to historical filters, the propagule pressure hypothesis (di Castri, 1989) postulates that variations in the invasion could simply be due to differences in the number of exotics arriving in the new community (Lonsdale, 1999). Factors influencing the number and dispersal potential of propagules are likely to be critical in regulating the establishing and future spread of introduced species (Murphy et al., 2006). Propagule pressure is a key factor in biological invasions. Increased availability of propagules increases the chances of establishment, naturalization and invasion (Rouget and Richardson, 2003). Thus, propagule analysis should perhaps be the first step in any analysis of invasion capacity. Acacia dealbata was deliberately introduced in Europe. At the moment, the presence of naturalized plots is a generous source of propagules that threatens the environment. Propagule pressure and anthropogenic activity were highly significantly associated with invasiveness and this pattern was generally consistent throughout taxa and invasion stages (Colautti et al., 2006). These research studies contended that future attempts to interpret characteristics of invaders should first attempt to dismiss potential confounding effects of propagule biases before other processes are implicated. This approach has not been followed for A. dealbata.

Before establishing in a new environment, an exotic plant also needs to overcome physiological filters, and at present there are two possible hypotheses that may be relevant to 
Acacia invasion in this regard. The fluctuating resource hypothesis (Davis et al., 2000) suggests that some exotics may be successful because they use resources in the new community that no local species used. Therefore, this hypothesis predicts that communities will be more susceptible to invasion when there is an increase in the amount of unused resources. In northwestern Spain, increased resource availability could result from a decrease in absorption rates of the native vegetation, resulting from forest fires or major civil construction. Acacia dealbata has biological traits that could provide it with an advantage over native vegetation in perturbed environments, but there is no information about how environmental variability in space and/or time may contribute to the invasiveness of A. dealbata in Europe. Snyder and Chesson (2004) suggest that information about the nature of fluctuations in the environment is needed as well as on the ability of native and invasive species to respond to environmental variability.

The disturbance hypothesis (Gray, 1979) complements this previous hypothesis, arguing that invasion occurs because native plants have not experienced the types and intensity of disturbance to which exotics are adapted. One of the factors increasing ecosystem invasibility is disturbance (Alpert et al., 2000), especially human disturbance. Therefore, it is difficult to separate the effect of changing environmental factors, biotic factors (e.g. species interactions) and human activities on species diversity (Chytrý et al., 2009). Some authors, on a local scale, thought that habitat types explain the level of invasion much better than alien propagule pressure. Moreover, it has been shown that patterns of habitat invasion are consistent among European regions with contrasting climates, biogeography, history and socioeconomic background (Chytrý et al., 2009). In northwestern Spain, Acacia dealbata was introduced to prevent slope collapse of the railway line and then dispersed throughout the region. However, there is no explicit quantification of the level of invasion on a regional scale for Europe and especially for A. dealbata in relation to habitat or disturbance type. Reductions in diversity due to disturbance create empty niches in an environment with few native species, so that the site becomes more susceptible to invasion, due to an increase in the amount of unused resources (Mack et al., 2000).

When Acacia manages to colonize a new habitat, it enters into biotic relations with the autochthonous flora and fauna and needs to overcome biotic filters that constrain establishment and subsequent naturalization of the new environment (Theoharides and Dukes, 2007). The hypothesis applicable here is the enemy release hypothesis (Elton, 1958), which suggests that colonization of new locations and increase in population density occur because the invader plant is released from specialist enemies that would otherwise suppress its population expansion (see also Keane and Crawley, 2002) so that exotics gain competitive advantage over native species that can be attacked by their native enemies. There are no consistent studies linking A. dealbata with the community of invertebrates in Europe, but Procheş et al. (2008) clearly demonstrated that herbivores, but not other insects, are scarce in the communities of invasive Acacias in South Africa's Western Cape compared with those present at the place of origin. A. dealbata alters beetle (Coleoptera) assemblage structure in the grasslands of the Drakensberg region, South Africa. Coleoptera richness and especially abundance values were found to be significantly lower in the invaded stands compared with grassland (Coetzee et al., 2007). Clearly, A. dealbata invasion of new areas of Africa has a substantial negative impact on invertebrates and the number of herbivores decreases in their environment. It is reasonable to expect that A. dealbata is also less attacked by herbivores in the invaded range in Europe.

Development of this hypothesis includes the Evolution of Increased Competitive Ability Hypothesis (Blossey and Nötzold, 1995) and the Novel Weapons Hypothesis (Callaway and Aschehoug, 2000). The first argues that exotics long liberated from their specialist enemies can reallocate resources used in resistance to other traits, providing greater competitive advantage in response to selection in the area of introduction. The novel weapons hypothesis suggests that invasive plants exude allelochemicals that are relatively ineffective against welladapted neighbours in the original habitats but that are highly inhibitory to native plants in the receiving habitats, or that can act as mediators of new plantsoil microbial interactions. Evolutionary relationships among plants, and perhaps coevolution, are a key part of the novel weapons hypothesis (Inderjit et al., 2006). The production of allelochemicals by $A$. dealbata in the introduced range is well documented (Carballeira and Reigosa, 1999; Lorenzo et al., 2008). Although we do not know the chemical composition of the exudates and leachates of $A$. dealbata well, the presence of sterols, $p$-hydroxycinnamic acids, chalcone glycosides, iminoacids and triterpenes has been published (Freire et al., 2005; Freire et al., 2007; Imperato, 1982; Kunii et al., 1996; Pereira et al., 1996), some of them well known as allelochemicals.

When invaders have achieved naturalization, they can spread through interaction with the fauna of the receiving region and/or through the appropriate vegetative traits (Sharma et al., 2005b). There is some evidence to suggest that invasion may be enhanced by the establishment of facilitative interactions between the invasive plant and other organisms, such as pollinators (Bruno et al., 2003).

Availability of propagules, habitat types, competitive advantage, competitive ability and allelopathy, as well as other relevant processes related to invasion, must work in concert with a whole suite of ecological processes, and it would not be reasonable to expect that all of them act identically, invading all the ecosystems. Taking into account the biological characteristics studied in A. dealbata and the information available for other related species, it seems hard to believe in the existence of a single factor or one single hypothesis that controls the complicated process of the invasion. Nevertheless, the novel weapons hypothesis, the enemy release hypothesis and disturbance hypothesis are perfectly acceptable in northwestern Spain in relation to A. dealbata invasion (Lorenzo et al., 2008). Testing these major hypotheses for invasions requires comparative biogeographical approaches (Hierro et al., 2005).

Although only based on partial evidence, it might suggest that the success of A. dealbata as an invader in Europe has several reasons. First, it was introduced by man due to its beauty and ability of setting its roots through sloping lands. 
This led to the formation of small stands that acted as donors of propagules into new areas. Secondly, successful invasion is related to the low specificity of pollinators (open flowers) and dispersants (low energy and low specificity). This means that when the propagules are in a new ecosystem, they can spread around to favorable conditions. However, this is only the first part of the story. The review of the literature published so far allows us to argue that A. dealbata is a species that takes advantage of disruption, especially when fire is present and in relation to specific weapons that allow $A$. dealbata to become a real and strong competitor. We think that there are several ecophysiological characteristics that could lead to its invasive capacity. Firstly, A. dealbata has some vegetative traits that play a key role in its success in Europe: clonal growth ensures that this plant can become dominant once established and may reduce biodiversity in the understory, changing soil conditions (this is in part due to its ability in nitrogen fixation, but especially to its capacity to sprout). The second idea concerns the allelopathic ability of the plant, leading to inhibition of other species. Although more information is needed to affirm the role of allelopathy in the invasion of A. dealbata within the meaning of the novel weapons hypothesis, the evidence is sufficient for us to at least say that the allelopathic properties of this plant in combination with the dates on which more allelochemicals are released help to improve its competitive capacity. Finally, there are some secondary benefits that reinforce, even without knowing its size, the action of other hypotheses, such as the absence of specific seed predators.

Acknowledgements: We thank the Xunta de Galicia for funding the project "Estudio del componente alelopático en la capacidad invasiva de la mimosa (Acacia dealbata Link) en el bosque y las plantaciones forestales gallegas" PGIDIT05RAG31001PR, the project "Estudio da capacidade invasora de Acacia dealbata: mecanismos de control integrados e sustentabilidade" 08MDS033310PR and The Consellería de Innovación e Industria for Paula Lorenzo's Ph.D. grant. Finally, we thank Carlos Bolaño, Eva Pazos, Tamara Rodríguez and M. Iftikhar Hussain for their invaluable assistance. We also thank the two anonymous referees that with their helpful comments have improved the manuscript.

\section{REFERENCES}

Adams M.A. and Attiwill P.M., 1982. Nitrogen mineralization and nitrate reduction in forest. Soil. Biol. Biochem. 14: 197-202.

Aguiar F.C., Moreira I., and Ferreira M.T., 2001. Exotic and native vegetation establishment following channelization of a western Iberian river. Regul. Rivers. Res. Manage. 17: 509-526.

Almeida J.D. and Freitas H., 2006. Exotic flora of continental Portugal a reassessment. Botanica Compluteusis 30: 117-130.

Alpert P., Bone E., and Holzapfel C., 2000. Invasiveness, invisibility and the role of environmental stress in the spread of non-native plants. Perspective Plant Ecol. Evol. Systematics 3: 52-66.

Anwar C., 1992. The growth of shorea seedlings on soil media of several age levels of Acacia mangium stands. Bul. Penelit. Hutan 544: 9-16.

Austin D.F., 1978. Exotic plants and their effects in southeastern Florida. Environ. Conserv. 5: 25-34.

Ball M.C., Butterworth J., Roden J.S., Christian R., and Egerton J.J.G., 1995. Applications of chlorophyll fluorescence to forest ecology. Aust. J. Plant Physiol. 22: 311-319.
Bashir Hussain S., 1991. Some observations on the effect of forest tree species on ground vegetation at Pabbi Forest, Kharian. Pak. J. For. 41: $173-177$.

Bauhus J., van Winden A.P., and Nicotra A.B., 2004. Aboveground interactions and productivity in mixed-species plantations of Acacia mearnsii and Eucalyptus globulus. Can. J. For. Res. 34: 686-694.

Bernhard-Reversat F., 1999. The leaching of Eucalyptus hybrids and Acacia auriculiformis leaf litter: laboratory experiments on early decomposition and ecological implications in Congolese tree plantations. Appl. Soil Ecol. 12: 251-261.

Blakesley D., Allen A., Pellny T.K., and Roberts A.V., 2002. Natural and induced polyploidy in Acacia dealbata Link and Acacia mangium Wild. Ann. Bot. 90: 391-398.

Blossey B. and Nötzold R., 1995. Evolution of increased competitive ability in invasive non-indigenous plants: a hypothesis. J. Ecol. 83: 887889.

Broadhurst L.M. and Young A.G., 2006. Reproductive constraints for the long-term persistence of fragmented Acacia dealbata (Mimosaceae) populations in southeast Australia. Biol. Conserv. 133: 512-526.

Brown J., Enright N.J., and Miller B.P., 2003. Seed production and germination in two rare and three common co-occurring Acacia species from south-east Australia. Austral Ecol. 28: 271-280.

Brown J.R. and Carter J., 1998. Spatial and temporal patterns of exotic shrub invasion in an Australian tropical grassland. Landsc. Ecol. 13: 93-102.

Bruno J.F., Stachowicz J.J., and Bertness, 2003. Inclusion of facilitation into ecological theory. Trends Ecol. Evol. 18: 119-125.

Callaway R.M. and Aschehoug E.T., 2000. Invasive plants versus their new and old neighbors: a mechanism for exotic invasion. Science 290: 521-523.

Callaway R.M. and Ridenour W.M., 2004. Novel weapons: invasive success and the evolution of increased competitive ability. Front. Ecol. Environ. 2: 436-443.

Callaway R.M., Pennings S.C., and Richards C.L., 2003. Phenotypic plasticity and interactions among plants. Ecol. 84: 1115-1128.

Carballeira A. and Reigosa M.J., 1999. Effects of natural leachates of Acacia dealbata Link in Galicia (NW Spain). Bot. Bull. Acad. Sin. 40: 87-92.

Carr G.W., 2001. Australian plants as weeds in Victoria. Plant Prot. Q. 16: $124-125$.

Cheal D., 2002. Acacia obtusifolia - introduction and spread in native bush. Vic. Nat. 119: 231-232.

Chou C.H., Fu C.Y., Li S.Y., and Wang Y.F., 1998. Allelopathic potential of Acacia confusa and related species in Taiwan. J. Chem. Ecol. 24: 2131-2150.

Chytrý M., Pyšek P., Wild J., Pino J., Maskell L.C., and Vilà M., 2009. European map of alien plant invasions based on the quantitative assessment across habitats. Divers. Distrib. 15: 98-107.

Coetzee B.W.T., van Rensburg B.J., and Robertson M.P., 2007. Invasion of grasslands by silver wattle, Acacia dealbata (Mimosaceae), alters beetle (Coleoptera) assemblage structure. Afric. Entomol. 15: $328-$ 339.

Colautti R.I., Grigorovich I.A., and MacIsaac H.J., 2006. Propagule pressure: a null model for biological invasions Biol. Invasions 8: $1023-$ 1037.

Cronk Q.B. and Fuller J.L., 1995. Plant invaders, Chapman and Hall, London, UK.

Danthu P., Ndongo M., Diaou M., Thiam O., Sarr A., Dedhiou B., and et al., 2003. Impact of bush fire on germination of some West African acacias. For. Ecol. Manage. 173: 1-10.

Davidson D.W. and Morton S.R., 1984. Dispersal adaptations of some Acacia species in the Australian arid zone. Ecology 65: 1038-1051.

Davis M.A., Grime J.P., and Thompson K., 2000. Fluctuating resources in plant communities: a general theory of invasibility. J. Ecol. 88: 528-534.

De Neergaard A., Saarnak C., Hill T., Khanyile M., Berzosa A.M., and Birch-Thomsen T., 2005. Australian wattle species in the 
Drakensberg region of South Africa - an invasive alien or a natural resource? Agric. Syst. 85: 216-233.

Dennill G.B. and Donnelly D., 1991. Biological control of Acacia longifolia and related weed species (Fabaceae) in South Africa. Agric. Ecosyst. Environ. 37: 115-135.

Di Castri F., 1989. History of biological invasions with special emphasis on the Old World. In: Drake J.A., Mooney H.A., di Castri F., Groves R.H., Kruger F.J., Rejmánek M., and Williamson M. (Eds.), Biological invasions: a global perspective, John Wiley \& Sons, New York, USA.

Dudley J.P., 1999. Seed dispersal of Acacia erioloba by African bush elephants in Hawange National Park, Zimbabwe. Afr. J. Ecol. 37: 375-385.

Edwards W. and Westoby M., 1996. Reserve mass and dispersal investment in relation to geographic range of plant species: phylogenetically independent contrasts. J. Biogeogr. 23: 329-338.

Elton C.S., 1958. The ecology of invasions by animals and plants, Methuen, London, UK.

Freire C.S., Coelho D.S., Santos N.M., Silvestre A.J., and Pascoal Neto C., 2005. Identification of $\Delta^{7}$-phytosterols and phytosteryl glucosides in the wood and bark of several Acacia species. Lipids 40: 317-322.

Freire C.S.R., Silvestre A.J.D., and Pascoal Neto C., 2007. Demonstration of long-chain $n$-alkyl caffeates and $\Delta^{7}$-steryl glucosides in the bark of Acacia species by gas chromatography-mass spectrometry. Phytochem. Anal. 18: 151-156.

French K. and Major R.E., 2001. Effect of an exotic Acacia (Fabaceae) on ant assemblages in South African fynbos. Austral Ecol. 26: 303-310.

Gerald E. and Obua J., 2005. Tree condition and natural regeneration in disturbed sites of Bwindi Impenetrable Forest National Park, southwestern Uganda. Trop. Ecol. 46: 99-111.

Gómez C. and Espadaler X., 1998. Myrmecochorous dispersal distances: a world survey. J. Biogeogr. 25: 573-580.

González L., Souto X.C., and Reigosa M.J., 1995. Allelopathic effects of Acacia melanoxylon R.Br. phyllodes during their decomposition. Forest Ecol. Manage. 77: 53-63.

Gray A., 1879. The predominance and pertinacity of weeds. Am. J. Sci. Arts 118: 161-167.

Hadacek F., 2002. Secondary metabolites as plant traits: current assessment and future perspectives. Crit. Rev. Plant Sci. 21: 273-322.

Heil M., Delsinne T., Hilpert A., Schürkens S., Andary C., Linsenmair K.E. et al., 2002. Reduced chemical defense in ant-plants? A critical re-evaluation of a widely accepted hypothesis. Oikos 99: 457-468.

Hickey J.E., 1994. A floristic comparison of vascular species in Tasmanian oldgrowth mixed forest with regeneration resulting from logging and wildfire. Aust. J. Bot. 42: 383-404.

Hierro J.L., Maron J.L., and Callaway R.M., 2005. A biogeographical approach to plant invasions: the importance of studying exotics in their introduced and native range. J. Ecol. 93: 5-15.

Hoffmann J.H., Impson F.A.C., Moran V.C., and Donnelly D., 2002. Biological control of invasive golden wattle trees (Acacia pycantha) by a gall wasp, Trichilogaster sp. (Hymenoptera: Pteromalidae), in South Africa. Biol. Control 25: 64-73.

Horvitz C.C. and Beattie A.J., 1980. Ant dispersal of Calathea (Marantaceae) seeds by carnivorous ponerines (Formicidae) in a tropical rain forest. Am. J. Bot. 67: 321-326.

Hunt A.M., Unwin G.L., and Beadle C.L., 1999. Effects of naturally regenerated Acacia dealbata on the productivity of a Eucalyptus nitens plantation in Tasmania, Australia. For. Ecol. Manage. 117: 75-85.

Imperato F., 1982. A chalcone glycoside from Acacia dealbata. Phytochemistry 21: 480-481.

Inderjit, Callaway R.M., and Vivanco J.M. 2006. Plant biochemistry helps to understand invasion ecology. Trends Plant Sci. 11: 574-580.

Jadhav B.B. and Gaynar D.G., 1992. Allelopathic effects of Acacia auriculiformis A. Cunn on germination of rice and cowpea. Indian J. Plant. Physiol. 35: 86-89.

Keane R.M. and Crawley M.J., 2002. Exotic plant invasions and the enemy release hypothesis. Trends Ecol. Evol. 17: 164-170.
Kenrick J., 2003. Review of pollen-pistil interactions and their relevance to reproductive biology of Acacia. Aust. Syst. Bot. 16: 119-130.

Kriticos D.J., Sutherst R.W., Brown J.R., Adkins S.W., and Maywald G.F., 2003b. Climate change and the potential distribution of an invasive alien plant: Acacia nilotica ssp. indica in Australia. J. Appl. Ecol. 40: 111-124.

Kulkarni M.G., Sparg S.G., and Van Staden J., 2007. Germination and post-germination response of Acacia seeds to smoke-water and butenolide, a smoke-derived compound. J. Arid Environ. 69: 177187.

Kunii Y., Otsuka M., Kashino S., Takeuchi H., and Ohmori S., 1996. 4Hydroxypipecolic acid and pipecolic acid in Acacia species: their determination by High-Performance Liquid Chromatography, its application to leguminous plants, and configuration of 4-hydroxypipecolic acid. J. Agric. Food. Chem. 44: 483-487.

Lake J.C. and Leishman M.R., 2004. Invasion success of exotic plants in natural ecosystems: the role of disturbance, plant attributes and freedom from herbivores. Biol. Conserv. 117: 215-226.

Lambers H., Chapin III F.S., and Pons T.L., 1998. Plant physiological ecology, Springer, Berlin, Germany.

Lamprey H.F., 1967. Notes on the dispersal and germination of some tree seeds through the agency of mammals and birds. East Afr. Wildl. J. 5: $179-180$.

Lamprey H.F., Halevy G., and Makacho S., 1974. Interactions between Acacia, bruchid seed beetles and large herbivores. East Afr. Wildl. J. 12: 81-85.

Lonsdale W.M., 1999. Global patterns of plant invasions and the concept of invisibility. Ecology 80: 1522-1536.

Lorenzo P., Pazos-Malvido E., González L., and Reigosa M.J., 2008. Allelopathic interference of invasive Acacia dealbata: physiological effects. Allelopathy J. 22: 452-462.

Lortie C.J., Brooker R.W., Choler P., Kikvidze Z., Michalet R., Pugnaire F.I., and Callaway R.M., 2004. Rethinking plant community theory. Oikos 107: 433-438.

Mack R.N., Simberloff D., Lonsdale W.M., Evans H., Clout M., and Bazzaz F.A., 2000. Biotic invasions: causes, epidemiology, global consequences, and control. Ecol. Appl. 10: 689-710.

Marchante H., Marchante E., Buscardo E., Maia J., and Freitas H., 2004. Recovery potential of dune ecosystems invaded by the exotic species Acacia longifolia. Weed Technol. 18: 1427-1433.

Martínez J., Vega-Garcia, C., and Chuvieco, E., 2009. Human-caused wildfire risk rating for prevention planning in Spain. J. Environ. Manag. 90: 1241-1252.

Maslin B.R., Miller J.T., and Seigler D.S., 2003. Overview of the generic status of Acacia (Leguminosae: Mimosoideae). Aust. Syst. Bot. 16: $1-18$.

Maslin R. and McDonald M.W., 2004. Acacia Search. Evaluation of Acacia as a woody crop option for southern Australia, RIRDC. Union Offset Printers, Canberra, Australia.

May B.M. and Attiwill P.M., 2003. Nitrogen-fixation by Acacia dealbata and changes in soil properties 5 years after mechanical disturbance or slash-burning following timber harvest. For. Ecol. Manage. 181: 339-355.

Midgley J.J. and Bond W.J., 2001. A synthesis of the demography of African acacias. J. Trop. Ecol. 17: 871-886.

Murphy H.T., Van der Wal, J., Lovett-Doust L., and Lovett-Doust J., 2006. Invasiveness in exotic plants: immigration and naturalization in an ecological continuum. In: Cadotte M.W., McMahon S.M., and Fukami T. (Eds.), Conceptual ecology and invasion biology: reciprocal approaches to nature, Dordrecht, Netherlands.

Or K. and Ward, 2003. Three-way interactions between Acacia, large herbivores and bruchid beetles: a review. Afr. J. Ecol. 41: 257-265.

Orchard A.E. and Maslin B.R., 2003. Proposal to conserve the name Acacia (Leguminosae: Mimosoideae) with a conserved type. Taxon 52: $362-363$. 
Osunkoya O.O., Bujang D., Moksin H., Wimmer F.L., and Holige T.M., 2004. Leaf properties and construction costs of common, cooccurring plant species of disturbed heath forest in Borneo. Aust. J. Bot. 52: 499-507.

Osunkoya O.O., Othman F.E., and Kahar R.S., 2005. Growth and competition between seedlings of an invasive plantation tree, Acacia mangium, and those of a native Borneo heath-forest species, Nelastoma beccarianum. Ecol. Res. 20: 205-214.

Pereira F.B.M., Domingues F.M.J., and Silva A.M.S., 1996. Triterpenes from Acacia dealbata. Nat. Prod. Lett. 8: 97-103.

Pohlman C.L., Nicotra A.B., and Murray B.R., 2005. Geographic range size, seedling ecophysiology and phenotypic plasticity in Australian Acacia species. J. Biogeogr. 32: 351.

Procheş Ş., Wilson J.R.U., Richardson D.M., and Chown S.L., 2008. Herbivores, but not other insects, are scarce on alien plants. Austral Ecol. 33: 691-700.

Rafiqul Hoque A.T.M., Ahmed R., Uddin M.B., and Hossain M.K., 2003. Allelopathic effect of different concentration of water extracts of Acacia auriculiformis leaf on some initial growth parameters of five common agricultural crops. Pak. J. Agron. 2: 92-100.

Rama Devi S. and Prasad M.N.V., 1991. Tannins and related polyphenols from ten common Acacia species of India. Bioresour. Technol. 36: 189-192.

Razanamandranto S., Tigabu M., Neya S., and Oden P.C., 2004. Effects of gut treatment on recovery and germinability of bovine and ovine ingested seeds of four woody species from the Sudanian savanna in West Africa. Flora 199: 389-397.

Reigosa M.J., 1987. Estudio del potencial alelopático de Acacia dealbata Link. Ph.D. thesis, Universidad de Santiago, Santiago de Compostela, Spain.

Reigosa M.J., Souto X.C., and Gonzalez L., 1999. Effect of phenolic compounds on the germination of six weeds species. Plant Growth Regul. 28: 83-88.

Rice E.L., 1984. Allelopathy, Acacemic Press, Orlando, Florida.

Rouget M. and Richardson D.M., 2003. Inferring process from pattern in plant invasions: a semimechanistic model incorporating propagule pressure and environment factors. Am. Nat. 162: 713-724.

Schumann W., Little K.M., and Eccles N.S., 1995. Suppression of seed germination and early seedling growth by plantation harvest residues. S. Afr. J. Plant Soil 12: 170-172.

Sedgley M. and Harbard J., 1993. Pollen storage and breeding system in relation to controlled pollination of four species of Acacia (Leguminosae, Mimosoideae). Aust. J. Bot. 40: 601-609.
Seigler D.S., 2002. Economic potential from Western Australian Acacia species: secondary plant products. Conserv. Sci. W. Aust. 4: 109116.

Seigler D.S., 2003. Phytochemistry of Acacia-sensu lato. Biochem. Syst. Ecol. 31: 845-873.

Sharma G.P., Raghubanshi A.S., and Singh J.S., 2005a. Lantana invasion: An overview. Weed Biol. Manag. 5: 157-165.

Sharma G.P., Singh J.S., and Raghubanshi A.S., 2005b. Plant invasions: emerging trends and future implications. Curr. Sci. India 88: 726734.

Sheppard A.W., Shaw R.H., and Sforza R., 2006. Top 20 environmental weeds for classical biological control in Europe: a review of opportunities, regulations and other barriers to adoption. Weed Res. 46: 93-117.

Snyder R.E. and Chesson, P., 2004. How the scales of dispersal, competition, and environmental heterogeneity interact of affect coexistence. Am. Nat. 164: 633-650.

Souto X.C., Bolano J.C., Gonzalez L., and Reigosa M.J., 2001. Allelopathic effects of tree species on some soil microbial populations and herbaceous plants. Biol. Plant. 44: 269-275.

Spooner P.G., 2005. Response of Acacia species to disturbance by roadworks in roadside environments in southern New Wales, Australia. Biol. Conserv. 122: 231-242.

Stone G.N., Raine N.E., Prescott M., and Willmer P.G., 2003. Pollination ecology of acacias (Fabaceae, Mimosoideae). Aust. Syst. Bot. 16: $103-118$.

Sultan S.E., 1995. Phenotypic plasticity and plant adaptation. Acta Bot. Neerl. 44: 363-383.

Theoharides K.A. and Dukes J.S., 2007. Plant invasion across space and time: factors affecting nonindigenous species success during four stages of invasion. New Phytol. 176: 256-273.

Tutin T.G., Burger N.A., Chater A.O., Edmonsen J.R., Heywood V.H., Moore D.M. et al., 2001. Flora Europaea V, Cambridge University Press, Cambridge, UK.

Tybirk K., 1993. Pollination, breeding system and seed abortion in some African acacias. Bot. J. Linn. Soc. 112: 107-137.

Varela O. and Bucher E.H., 2006. Passage time, viability, and germination of seeds ingested by foxes. J. Arid Environ. 67: 566-578.

Whitney K.D., 2002. Dispersal for distance? Acacia ligulata seeds and meat ants Iridomyrmex viridiaeneus. Austral Ecol. 27: 589-595.

Wilcock C. and Neiland R., 2002. Pollination failure in plants: why it happens and when it matters. Trends Ecol. Evol. 7: 270-277.

Wright I.J., Reich P.B., and Westoby M., 2001. Strategy shifts in leaf physiology, structure and nutrient content between species of high and low rainfall, and high and low nutrient habitats. Funct. Ecol. 15: $423-434$. 